\title{
PRINCIPLES OF MODERN PHYSIOTHERAPY AFTER SURGICAL TREATMENT OF LUMBAR SPINE PAIN (REVIEW ARTICLE)
}

\author{
Daniela Lyubenova, Tsvetelina Bizheva, Nikolay Izov, \\ Ivan Maznev, Antoaneta Dimitrova \\ National Sports Academy "Vassil Levski", Sofia, Bulgaria
}

\begin{abstract}
Summary
Low back pain is a common disorder and is an important and serious health and social problem. The prevalence and economic burden grow exponentially. Over 350000 people per year seek consultation with a neurologist and neurosurgeon because of lower back pain in Bulgaria. The pain is provoked most often by improper posture or lifting weights. It is strong and sometimes leads to significantly impaired performance and an inability to get out of bed. Walking and moving are difficult to impossible. Treatment can be conservative or operative. Neurosurgical techniques are continuously evolving in order to facilitate and optimize healing processes. Physiotherapy is essential for functional recovery of the patients after operation, related to overcome the complications, the fatigue and the delayed functional recovery. Various specialized methods as postisometric relaxation, proprioceptive neuromuscular facilitation, neurocognitive methodology of Perfetti, neurodevelopment treatment and therapeutic exercises for motor recovery are recommended in order to improve the independence and health related quality of life of the patients.
\end{abstract}

Keywords: physical therapy, low back pain

\section{Introduction}

Degenerative spinal diseases (DSD) are a significant medical, social and economic problem worldwide, resulting in the demand for different therapeutic strategies for DSD prevention and optimal treatment options. Lumbar spine surgeries as a result of degenerative diseases are associated with a prolonged hospital stay. A second operation is often necessary, and there is a risk of developing post-operative complications (Mannion et al., 2007). The number of patients undergoing spinal surgery, in Bulgaria and abroad, has been increasing. In the United States between 1999 and 2001 the frequency has increased by more than $200 \%$, and reached 61 operations per 100,000 population (Deyo et al., 2005). Data for Denmark is similar, where the number of operations between 1997 and 2003 has increased from 26 to 46 per 100000 . In recent years, early rehabilitation has been introduced in order to overcome complications and delayed recovery after surgical interventions (Langelotz et al., 2005). However, a pre-surgical program involving pre-rehabilitation, as well as early postoperative rehabilitation, has not been integrated yet (Nielsen et al., 2010). Data for Bulgaria is similar: Over 350,000 Bulgarians consult with a neurologist due to lower back, lumbar spine, and neck pain, on average annually. Most often the pain is provoked by an incorrect posture, sudden movement, or lifting heavy objects. Moreover, the pain is often strong and sometimes lead to a significant disability, inability to get out of bed, and difficulty during movement (Gerasimov, 2016). DSD are the most common surgical diseases of the spine, spinal cord and its nerve roots (Todorov et al., 2014). The high DSD frequency and treatment costs require a better understanding of contemporary surgical interventions by physiotherapists in order to develop suitable rehabilitation programs based on modern therapeutic approaches (Krajdzhikova, 2011, Lyubenova, 2011, Matzuridis et al., 2013, Nielsen).

\section{Etiology of degenerative spinal diseases}

The most common cause for DSD are the intervertebral disc changes associated with formation of spinal disc herniations, protrusions, intervertebral joints' changes, osteophytes, spondylolisthesis and other changes in the spine structures. Risk factors include the followings: heavy physical work, bad posture when lifting heavy objects, weak connective tissue, gender, old age, and others (Gerasimov, 2016).

Pathogenesis and pathophysiology of degenerative spinal diseases 
The vertebral column represents a perfectly balanced system of vertebrae. Intervertebral discs lay between adjacent vertebrae and act as shock absorbers. They take up the stresses to which the backbone is subjected, due to the fact that they are made of elastic tissue with high fluid content. The amount of liquid and elasticity of the discs, as well as their height, decrease with aging. This compromises the system balance and leads to increasing the pressure to the fibrous sheath that surrounds the gel-like core (nucleus pulposus) of the intervertebral disc, mainly to its rear end due to a physiological spine lordosis. In case of a sudden load on the vertebral column, it creates a possibility that a part of the disk core may tear or perforate the fibrous ring (annulus fibrosus) and herniate out by pressing a neighboring spinal cord nerve root. Strong pain then occurs due to nerve root irritation. The roots in the lumbar region of the spine are most commonly affected because the lumbar vertebrae carry the greatest weight of the body. If the muscles around a backbone are stronger, they can distribute some of the weight and prevent the disc prolapse. The formation of a disc herniation leads to a decrease of a disc height and plays an important role in the genesis of degenerative stenosis (Cholakov et al., 2008).

In spondylolisthesis, the body of the affected vertebra slips forward (along with the overlying vertebral column), and its arc remains in its place, back and curved upwards. A degenerative type of spondylolisthesis is a combination of degenerative changes in the intervertebral disc and remodeling of processi articulares at the level of the damage, which in turn progresses with age. At the stability in L5, spondylolisthesis occurs in level L4 due to degenerative changes in it (Gechev, 2002).

Clinical presentation of degenerative spinal diseases The most common cause of surgical intervention in DSD is the disc herniation, which results in the following symptoms: low back pain, paresthesia, and sensory disorders in the distal parts of the lower extremities and last two toes of the foot. The increased paravertebral muscle tone leads to extending the rear disc space between the vertebrae, reducing the compression from the disc prolapse, expanding the intervertebral foramina, and relieving the pressure on the roots. The ventral and dorsal body flexions are limited. A similar reflector mechanism that leads to increasing a muscle tone, is the scoliosis of the spine. The patients occupy an antalgic posture - standing slightly bent and distorted to one side, and lying down with a folded lower limb in order to avoid the painful tension of the sciatic nerve. When moving, they try to spare the affected lower extremity and lame. Muscle weakness, hypotension and muscle hypotrophy may occur in the corresponding myotome. A disc hernia at L5-S1 level affects S1 nervous root, and the tibial group of muscles is damaged. The foot is in an equinovarus position and the patients cannot occupy plantar flexion and walk on their tiptoes. In some cases, motor symptoms may be leading or only be manifested by a muscle hypotension (Shotekov, 2004).

Degenerative lumbar spinal stenosis is a leading cause of pain, impairment and loss of independence in older age. The clinical syndrome is known as a neurogenic claudication. It is characterized by bilateral or unilateral pain in the hip and the distal part of the lower extremities, weight, stiffness, tingling or weakness, which increases while walking and standing and decreases in sitting and bending forward positions (Suri et al., 2010; Ammendolia, 2014).

At first, the patients with spondylolisthesis complained of mild fatigue, especially while standing for a long period of time, sitting, or during physical effort, with consequent impossibility to stand in a vertical position for a long time. The pain occurs in the form of lumbar radiculalgia and can be caused by compression of a nervous root due to the presence of pathological mobility (in case of slightly expressed spondylolisthesis). A traumatic nerve root injury can be caused in the area of the facet vertebral joints that have been altered as a result of arthrosis (degenerative spondylolisthesis). It is typical that walking does not cause the pain to increase, whereas changing the body position, such as getting up, causes pain.

Development of a pain syndrome in women is often associated with pregnancy and childbirth. The lumbar lordosis is greatly increased. The disturbed statics require hard muscle work to maintain the trunk and the long lumbar musculature tension ( $\mathrm{mm}$. erectors trunci). As compensation, hypertrophy occurs in the back, thigh, and glutes muscles. The flexion movements are restricted, while the lateroflexions is free (Gechev, 2002).

Conservative and operative treatment in patients with degenerative spinal diseases 
Surgical treatment for DSD is recommended (disc, hernia, spondylolisthesis, stenosis) in the case that conservative treatment through medications, preformed physical factors, manual therapy and others has failed, and if pain and sensory symptoms are unaffected by medication and physiotherapeutic treatment for at least 4 to 6 weeks, as well as definite data from X-ray, MRI, CAT Scan.

After the surgical treatment, in about $15-30 \%$ of the patients with disc herniation and spondylolisthesis, paraesthesias, residual pain predominantly as lumbalgia than ischialgia, persist to varying degrees. Neurological deficits are influenced to varying degrees, depending on the duration and severity of the root compression. (Busarski et al., 2009; Kalevski, 2010; Mannion et al., 2009).

Physiotherapy after neurosurgery in patients with degenerative spinal diseases

Influence of physiotherapy on motor skills

In elderly people, problems with functional disorders (poor coordination, balance, strength and movement performance), neurological changes (loss of sensory and motor neurons), muscle changes (atrophy of type-2 muscle fibers), arthrosis, and osteoporosis further complicate the treatment.

Pilates exercises are suitable for positive influence on muscle strength, equilibrium and functional recovery (Granacher et al., 2013).

Targeted exercises for relaxation of muscles with reflexively increased tone and strengthening the weak musculature are essential for the functional recovery of the patients (Lyubenova, 2012; Lyubenova, 2015).

Ball exercises allow purposeful training of certain muscle groups of the trunk and the limbs (Bizheva, 2015).

It is appropriate to be included postisometric relaxation in the presence of muscle imbalance and increased muscle tone of $\mathrm{m}$. triceps surae, $\mathrm{m}$. illiopsoas, m. quadratus lumborum, m. piriformis, hip joint adductors and others (Kraĭdzhikova et al., 2005).

The reduced muscle strength of vertebral column extensors and abdominal musculature is associated with chronic and recurrent low back pain.
Motor control exercises, combined with resistance exercises, as well as mechanotherapy, achieve greater changes in the trunk muscle strength than if the resistance exercises are applied alone (Shahtahmassebi et al., 2014).

Stabilizing exercises from sitting to standing, combined with movements with increasing resistance, isometric exercises for spine extensors, motor control exercises, coordination and balance exercises, moving from stable to unstable support (ball), treadmill, and bicycle are recommended (Schubert et al., 2013).

\section{Influence of physiotherapy on the sensory disorders}

Stimulating proprioception during training activities by using unstable surfaces, leads to increased demands on the trunk muscles and improves the stability and balance. In search of a precise balance between stability and mobility, sensor-motor control plays much more important role than the strength or endurance of the trunk muscles. The central nervous system creates a stable basis for movement of the limbs through the cooperation of certain muscles (Borghuis et al., 2012).

The use of breathing exercises is appropriate, such as a combination of deep diaphragmatic breathing with slow counting, which leads to muscle relaxation. The postisometric relaxation has a marked pain reliever effect because it affects the segmental reflex arc through the nerve-reflection mechanisms(Bizheva, 2016).

\section{Influence of physiotherapy on the global movements related to transfer and walking}

Proprioceptive neuromuscular facilitation support the neuromuscular response by stimulating proprioceptors through postural stimuli, and improving the posture, equilibrium, coordination and functional activity of the patients. The methodology includes volitional, active and purposeful movements to restore the normal flexibility and mobility of the locomotor apparatus (Lyubenova, 2011; Bizheva, Lyubenova, 2016). Some authors recommend a physiotherapeutic program be performed for 6-8 weeks after surgery and to include the following: exercises in aerobic mode, treadmill, stretching, stabilizing exercises, exercises for improving the strength and endurance of the muscles of the back, abdomen and lower limbs, training in ergonomic performance of the movements, self 
motivation, and advice regarding how to lift and place objects (Mc Gregor et al ., 2012).

The optimal postoperative physiotherapy, applied to patients undergoing spinal surgery because of DSD, can make a significant contribution to improving the long-term outcome of this surgery. The restrictions on specific activities in the post-operative period, and in particular the recommended period during which the patients should comply with these restrictions, are still a subject of a study.

\section{Conclusion}

Physiotherapy is essential for functional recovery of the patients after neurosurgical treatment, and is related to overcoming the possible postoperative complications: pain and fatigue.

\section{Reference}

Ammendolia, C. (2014), Degenerative lumbar spinal stenosis and its imposters: three case studies, J Can Chiropr Assoc, Vol. 58 No. 3, pp. 312-319

Bizheva, Ts., Lyubenova, D. (2016), Prouchvane vŭrkhu vŭzmozhnostite na kineziterapiyata za terapevtichno povliyavane pri bolni s degenerativni spinalni zabolyavaniya sled operativno lechenie, Sedmi natsionalen kongres na AFB, 5-7 Yuni 2015, Sofia, Bulgaria, Sbornik nauchni dokladi v Sport i Nauka, Vol. 1, pp. 39-43

Bizheva, Ts. (2015), Funtsional'noye vosstanovleniye pri degenerativnykh zabolevaniyakh pozvonochnika. Sbornik konferentsii lechebnaya fizicheskaya kul'tura: dostizheniya i perspektivy razvitiya, Materialy IV Vserossiyskoy nauchno-prakticheskoy konferentsii s mezhdunarodnym uchastiyem, Moskva, Rossiya, 27-28 maya, 2015, pp. 26-30

Bizheva, Ts. (2016), Issledovaniye vliyaniya kineziterapii na osushchestvleniye povsednevnoy deyatel'nosti $\mathrm{v}$ rannem posleoperatsionnom periode posle laminektomii, Sbornik konferentsii lechebnaya fizicheskaya kul'tura: dostizheniya i perspektivy razvitiya, Materialy V Vserossiyskoy nauchno-prakticheskoy konferentsii s mezhdunarodnym uchastiyem, Moskva, Rossiya, 25-26 maya, 2016, pp. 44-48

Borghuis, J., Hof, A., Lemmink, K. (2008), The Importance of Sensory-Motor Control in Providing Core Stability, Sports Medicine, Vol. 38, No. 11, pp. 893-91

Busarski, V., Marinov, M., Gabrovski, St. (2009), Spinalna nevrokhirurgiya, Standarti i preporŭki po nevrokhirurgiya, Bŭlgarsko druzhestvo po nevrogirurgiya i assotsiatsiya na nevrokhirurzite v bŭlgariya, Sofiya, pp. 89-104

Cholakov, D., Kumchev, Y., Karaslavova, E. (2008), Diskova kherniya i degenerativna stenoza $\mathrm{v}$ lumbalniya otdel-vŭzrastovo razpredelenie, Medinfo, Vol.6, pp.475481

Deyo, R., Gray, D., Kreuter, W., Mirza, S., Martin, B. (2005), United States trends in lumbar fusion surgery for degenerative conditions, Spine, Vol. 30, pp. 1441-1445 Gerasimov, B. (2016), Diskogenni lumbosakralni radikuliti, Medical magazine, Vol. 1, pp. 14-17

Gechev, Ĭ. (2002), Osnovi na vertebrologiyata, VION, Sofiya, pp. 248-478

Granacher, U., Gollhofer, A., Hortobágyi, T., Reto, K., Muehlbauer, T. (2013), The Importance of Trunk Muscle Strength for Balance, Functional Performance, and Fall Prevention in Seniors: A Systematic Review, Sports Medicine, Vol. 43 No. 7, pp. 627-641

Kalevski, S. (2010), Persistirashti i retsidivirashti lumboisshialgii sled lumbalna diskektomiya. Etiologiya, lechenie, rezultati, Bulg Neurosurg, Vol. 15 No. 1-2, pp. $15-23$

Krădzhikova, L. (2011), Manualni metodi za mobilizatsiya pri muskulno-skeletni disfunktsii v oblastta na grŭbnachniya stŭlb, Avangard prima, Sofiya

Krădzhikova, L., Petkova, D., Andonova, T., Akhmedov Sh. (2005), Masazhna metodika za mekotǔkanna mobilizatsiya pri khronichen bolkov sindrom v lumbosakralnata oblast, Kineziterapiya i rekhabilitatsiya, Vol. 1-2, pp. $4-12$

Langelotz, C., Spies, C., Muller, J., Schwenk, W. (2005), 'Fast-track'-rehabilitation in surgery, a multimodal concept, Acta Chir Belg, Vol. 105, pp. 555-59

Lyubenova, D. (2011), Kineziterapiya pri nervni i psikhichni bolesti, BETAPRINT - EOOD, Sofiya

Lyubenova, D., Tityanova, E. (2012), Printsipi na sŭvremennata nevrorekhabilitatsiyata, Nevrosonologiya i mozŭchna khemodinamika, Vol.8 No.1, pp. 45-55

Lyubenova, D. (2015), Nevrorekhabilitatsiya, V: Uchebnik po nervni bolesti. Obshta nevrologiya. Tityanova, E., Sveti Kliment Okhridski, Sofiya, pp. 249-258

Mannion, A., Denzler, R., Dvorak, G., Grob, D. (2007), A randomised controlled trial of post-operative rehabilitation after surgical decompression of the lumbar spine, European Spine Journal, Vol. 16, No. 8, pp. 1101-1117 Mannion, A., Helbling, D., Pulkovski, N., Sprott, H. (2009), Spinal segmental stabilisation exercises for chronic low back pain: programme adherence and its influence on clinical outcome, European Spine Journal, Vol.18 No.12, pp. 985-998

Matzuridis, A., Kraydzhikova, L., Andonova T. (2013), Avtostreching dlya profilaktiki boley v spine u patsiyentov s osteoporozom, Sbornik konferentsii lechebnaya fizicheskaya kul'tura: dostizheniya i perspektivy razvitiya, Materialy II Vserossiyskoy nauchno-prakticheskoy konferentsii s mezhdunarodnym uchastiyem „Lechebnaya fizicheskaya kultura: Dostizheniya i perspektivy razvitiya", Moskva, Rossiya 27-28 maya 2013, pp.162165

Mc Gregor, H., Henley, A., Morris, T., Dore, C. (2012), Patients views on an education booklet following spinal surgery, Eur Spine J, Vol. 2, pp. 1609-1615

Nielsen, P., Andreasen, J., Asmussen, M., Tønnesen, H. (2008), Costs and quality of life for prehabilitation and early rehabilitation after surgery of the lumbar spine. MC Health Serv Res, Vol. 8, pp. 209

Nielsen, P., Jorgensen, L., Dahl, B., Pedersen, T., Tonnesen. H. (2010), Prehabilitation and early rehabilitation 
after spinal surgery: randomized clinical trial, Clinical Rehabilitation, Vol. 24, pp. 137-148.

Shahtahmassebi, B., Hebert, J., Stomski, N., Hecimovich, M. (2014), The Effect of Exercise Training on Lower Trunk Muscle Morphology, Sports Medicine, Vol. 44 No.10, pp. 1439-1458

Shotekov, P. (2004), Nevrologiya, Arso, Sofiya, pp. 55-57 Schubert, M., Helmbrencht, A., Schultz, Ch. (2013), Postoperative program after spine surgery, International Spine Center, Apexspine

Suri, P., Rainville, J., Kalichman, L., Katz, J. (2010), Does this older adult with lower extremity pain have the clinical syndrome of lumbar spinal stenosis? JAMA, Vol. 304 No.23, pp. 2628-36
Todorov, T., Todorov, I., Mikhaŭlova, M., Vladeva, E. (2014), Sŭvremenna fizikalna terapiya i rekhabilitatsiya pri diskova bolest, Varnenski meditsinski forum, Vol.3, No.1, pp.62-65

\section{Correspondence address:}

Professor Daniela Lyubenova, Ph. D.

Department of Physiotherapy and Rehabilitation

National Sports Academy "Vassil Levski” Sofia, Bulgaria Gurgulyat str. 1, 1000 Sofia, Bulgaria

Mobile: +359898776414

E-mail: lubenova@abv.bg 